\title{
First bipolar benthic brooder
}

\author{
Piotr Kuklinski1 ${ }^{1,2, *}$, David K. A. Barnes ${ }^{3}$ \\ ${ }^{1}$ Department of Zoology, Natural History Museum, Cromwell Road, London SW7 5BD, UK \\ ${ }^{2}$ Institute of Oceanology, Polish Academy of Sciences, ul. Powstanców Warszawy 55, Sopot 81-712, Poland \\ ${ }^{3}$ British Antarctic Survey, High Cross, Madingley Road, Cambridge CB3 0ET, UK
}

\begin{abstract}
A bipolar distribution is one in which a taxon occurs at high northern and southern latitudes but is absent in the latitudes between. In spite of the large distance between the Arctic and Antarctic, there are records of biota with bipolar distributions, both currently and in the geological past. To date, combined morphological and genetic studies of organisms such as bacteria and foraminifera have confirmed the occurrence of some species in both polar regions. Bipolar genera and families are also known in larger invertebrates, e.g. in crustaceans and molluscs, and a recent Census of Marine Life report suggested that more than 200 metazoan species may have bipolar distributions. Here we investigated specimens of the the cheilostome bryozoan Callopora weslawski from both Arctic and Antarctic localities. To our knowledge this is the first benthic brooder to be found in both polar regions and is the first record of a species of Callopora in Antarctic waters. We used scanning electron microscopy and statistical analyses to confirm the morphological identity of individuals. The encrusting nature of the species, its distribution in the deep Weddell Sea and its rarity mean that genetic confirmation of bipolarity may take years or decades. Possible paths of distribution are discussed, including the Pangea break-up, Plio-Pleistocene glaciations, isothermal submergence via offshelf or abyssal currents and anthropogenic transport.
\end{abstract}

KEY WORDS: Bipolar $\cdot$ Arctic $\cdot$ Antarctic $\cdot$ Bryozoa $\cdot$ Biodiversity Resale or republication not permitted without written consent of the publisher

\section{INTRODUCTION}

The bipolar distribution of biota is defined as the spread over a region in the high Northern and Southern Hemispheres, with a gap between the two (Ekman 1953, Stepanjants et al. 2006). Here we consider extreme bipolarity between the 2 polar regions. The Arctic and Antarctic regions share many similar environmental characteristics, including extreme seasonal light fluctuation supply, low water temperature, strong mixing and cold dense water production at the surface, seasonal sea-ice, benthic scour by icebergs, ice shelves and cyclical expansion and retreat of ice sheets during glaciations. However, the 2 polar regions also differ in many ways, such as in their structure (Antarctica is a continent surrounded by ocean, compared with ocean surrounded by continents in the Arctic), level of isolation, bathymetry and especially their geological histories. Following near-complete eradication of polar shelf faunas during the last glaciation, the Arctic has been reinvaded since the ice sheet retreat (about 14000 yr ago), mostly by biota of Atlantic and Pacific origin (and thus is geologically young, see Dunton 1992). In contrast, most Antarctic shelf fauna are endemic (Arntz et al. 1997) and have had little recent exchange with taxa in Atlantic, Indian and Pacific Oceans (e.g. see Hunter \& Halanych 2008) and so are likely to have recolonised from a combination of refugia, continental slopes or outlying archipelagos. A number of vertebrates (such as whales, seals and birds) migrate between the poles, but otherwise the distance between polar regions is considerable for most mega-, macro- and smaller fauna, even during glacial maxima (ice ages).

In spite of the $12000 \mathrm{~km}$ minimum distance (from the Polar Front north of South Georgia to the Labrador Sea) and major temperature or bathymetric extremes between the 2 polar regions, there are a number of 
records indicating potential bipolar biota distributions and/or exchanges both in the geological past and in recent times (Lindberg 1991, Crame 1993, Stepanjants et al. 2006, Pawlowski et al. 2007). This was first observed more than 150 yr ago (e.g. Ross 1847). Recent molecular studies have indicated strong genetic similarity of some widely distributed foraminifera, such as those which occur from the Arctic to Antarctic, from pelagic to deep bottom sea realms (Darling et al. 2000, Pawlowski et al. 2007). However in larger invertebrates, bipolar records are mainly at the genus or family level (see Crame 1993, Jazdzewski et al. 1995). Recently, the Census of Marine Life and Census of Antarctic Marine Life highlighted at least 235 species (including worms, crustaceans, pteropods, birds and whales) that have been reported from both polar regions. In the present study we present the first record of the occurrence of a cheilostomous bryozoan (Callopora weslawski Kuklinski and Taylor, 2006) in both the Arctic and Antarctic. This is also the first record of Callopora species within the Polar Front (Antarctic waters) (see Hayward 1995). As with other phyla (e.g. molluscs), there are, however, many bipolar bryozoan genera already known from the Arctic and Antarctic (e.g. Escharella, Microporella, Amphiblestrum) (see Kluge 1975, Hayward 1995). Previous putative records of bryozoan species (e.g. Idmidronea atlantica, Microporella ciliata) reported in both polar regions have been found, on closer morphological examination, to be previously undescribed species restricted in distribution to either the Arctic or Antarctic, or misidentifications (Moyano 1982, Hayward \& Ryland 1990, Ostrovsky \& Taylor 1996, Kuklinski \& Taylor 2008a).

In contrast to previously confirmed bipolar species, all of which are migratory or mobile to some degree, the bryozoan Callopora weslawski is a sessile animal with low dispersal potential. Its reproductive strategy involves the production of lecithotrophic larvae typically able to stay in the water column from a few minutes to hours, rarely up to $5 \mathrm{~d}$ prior to settlement and metamorphosis (Ryland 1974, Cook \& Chimonides 1985). The exact larval duration of $C$. weslawski is unknown, and Antarctic cheilostomes may have longer larval development and durations than those elsewhere (Barnes \& Clarke 1998), but even days or weeks would not enable dispersal of thousands of kilometres, especially from north to south (as the strongest Antarctic current is circumpolar). This suggests that the potential for colonization of new areas is very limited. Here we compare morphological characters of individuals of C. weslawski from Arctic and Antarctic samples and we discuss possible mechanisms of species transfer between 2 such extremely distant localities.

\section{MATERIALS AND METHODS}

Callopora weslawski appeared in the literature for the first time in 1916 under the name Membranipora whiteavesi, recorded in northeast Greenland (Levinsen 1916). The species was also misidentified later as C. whiteavesi by several other authors including Kluge (1975) and Gostilovskaya (1978). Recent scanning electron microscopy (SEM) revealed this species to be undescribed (Kuklinski \& Taylor 2006). According to the literature, this is a circumarctic species (Kluge, 1975) and confirmed records to date (with SEM analysis) include East Greenland, Spitsbergen, Franz Joseph Land and the Kara Sea (Kuklinski \& Taylor 2006, Kuklinski \& Bader 2007). In the Arctic, the species has been recorded as deep as $500 \mathrm{~m}$, but seems to be most common and abundant between 100 and $300 \mathrm{~m}$ (Kluge 1975, Kuklinski \& Taylor 2006). This species has been confirmed on rocks, shells and other hard objects, but the scarcity of reports suggests that it has not been recorded as common anywhere to date (Kluge 1975). For more details of Arctic material examination and taxonomic description, see Kuklinski \& Taylor (2006).

Antarctic material was collected during the R/V 'Polarstern' expeditions to the Weddell Sea between 2005 (ANDEEP III: Antarctic DEEP sea) and 2007 (ANDEEP SYSTCO: Antarctic DEEP sea, SYSTem Coupling). Two colonies were found, one at $2190 \mathrm{~m}$ on a rock $\left(70^{\circ} 04.58^{\prime} \mathrm{S}, 03^{\circ} 19.66^{\prime} \mathrm{W}\right)$ and the other at $1030 \mathrm{~m}$ on a sabellariid polychaete tube $\left(71^{\circ} 18.35^{\prime} \mathrm{S}, 13^{\circ} 57.71^{\prime} \mathrm{W}\right)$. SEM of all the material was undertaken with a lowvacuum instrument (LEO 1455-VP) capable of imaging large, uncoated specimens using back-scattered electrons. Zooecial measurements were made on SEM images using the software ImageJ.

The study material is lodged in the Natural History Museum, London and the Zoological Institute of the Russian Academy of Sciences, St. Petersburg.

Similarities in zooid and ovicell length to width ratios of individuals from the Arctic and Antarctic were analysed using 1-way ANOVA. Data were log-transformed prior to analysis to improve normality and homogeneity.

\section{RESULTS AND DISCUSSION}

The present study represents the first record of a benthic brooding organism, the bryozoan Callopora weslawski, occurring in both the Arctic and Antarctic. Although bipolarity among marine bryozoans was discussed as early as 1904, no species in particular were mentioned (Calvet 1904). Recent species of Calloporidae are distributed worldwide across all climatic zones, from the poles to the tropics. However, species 
of the genus Callopora seem to be limited in their distribution to Northern Hemisphere with no records from the tropical zone (Bock 2009). Our morphological analysis, using SEM, shows that both Arctic and Antarctic individuals are similar (Fig. 1). Zooid size of specimens did differ between individuals from the Arctic and Antarctic, but their general morphological appearence was similar (Table 1, Fig. 1). Zooid length to width ratio and ovicell length to width ratio were not significantly different between individuals from both polar seas (ANOVA, $F_{1,24}=1.001, \mathrm{p}=0.327$, and $F_{1,6}=$ 0.005, $\mathrm{p}=0.944$, respectively) (Table 1 ). Additionally, individuals of $C$. weslawski from the Arctic and Antarctic share the following similarities: small, transversely elliptical pore chambers facing frontally, laterally and distolaterally; finely pustulose narrow cryptocysts, sloping downward; elliptical or oval opesia; circumopesial mural spines, as well as spines arising outside the mural rim on lateral gymnocysts; uncalcified ovicell ectoocium, apart from a narrow crescent around lateral and distal perimetry; and finely pustulose entoocium. Some Antarctic individuals seem to have a broader cryptocyst than Arctic specimens. Also, opesia are often pear-shaped in Antarctic individuals. Although these characters seem to be more frequent in Antarctic individuals, they have also been recorded in specimens from the Arctic.

Differences in zooid size and opesia shape and, generally, phenotypic variation in colonial animals can often be ascribed to factors such as microenvironment, ontogeny and astogeny (Boardman \& Cheetham 1973, Schopf 1976, Hageman et al. 1999). The Antarctic specimens are one-third smaller than those in the Arctic, but this could be due to these (small) colonies still being at the stage of astogenetic change. Zooid size may still increase through early colony development and then level off (zone of astogenetic repetition); however, since there were already some zooids with ovicells (structures in which embryos develop), at least one colony appears to have been reproductively mature. Thus differences related to ontogeny or astogeny

Table 1. Callopora weslawski. Measurements of zooidal characteristics of Arctic and Antarctic bryozoan specimens (mean $\pm \mathrm{SD}$, number of measurements in parentheses)

\begin{tabular}{|lcc|}
\hline Zooidal characteristic & Arctic & Antarctic \\
\hline Zooid length (mm) & $0.92 \pm 0.08(15)$ & $0.54 \pm 0.04(11)$ \\
Zooid width (mm) & $0.56 \pm 0.03(15)$ & $0.34 \pm 0.03(11)$ \\
Zooid length:width ratio & $1.65 \pm 0.17(15)$ & $1.56 \pm 0.21(11)$ \\
Ovicell length (mm) & $0.25 \pm 0.01(4)$ & $0.17 \pm 0.02(4)$ \\
Ovicell width (mm) & $0.29 \pm 0.02(4)$ & $0.20 \pm 0.01(4)$ \\
Ovicell length:width ratio & $0.86 \pm 0.13(4)$ & $0.86 \pm 0.12(4)$ \\
No. circumopesial mural spines & $13-18(9)$ & $12-16(10)$ \\
No. spines located outside mural rim & $5-10(7)$ & $4-12(7)$ \\
\hline
\end{tabular}
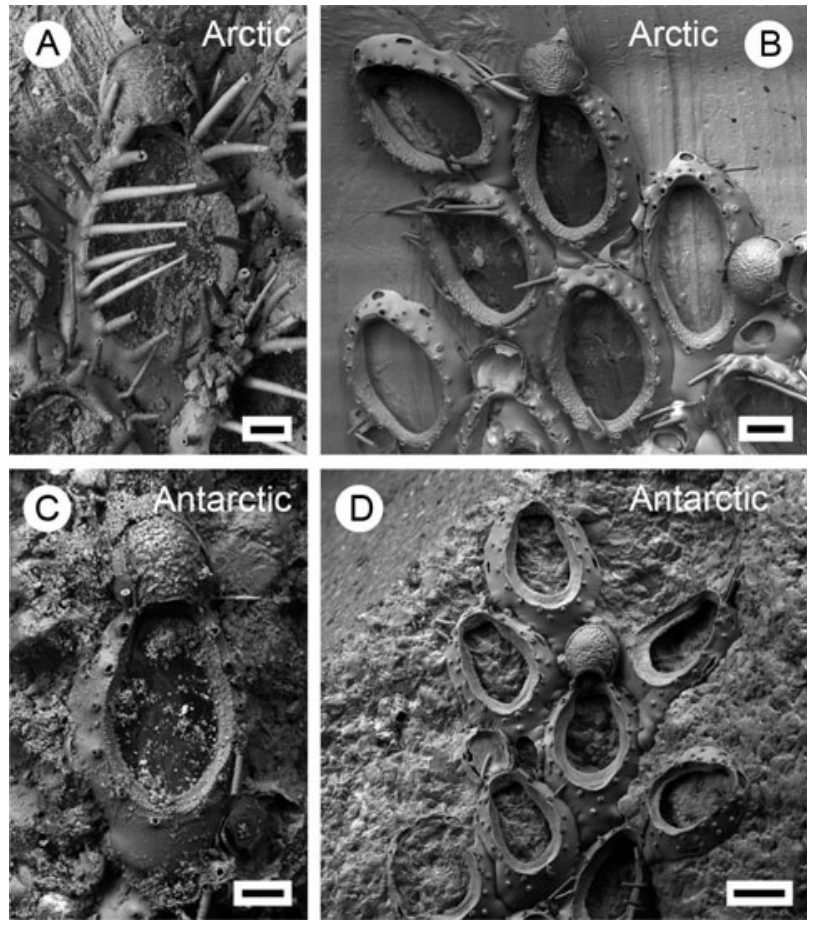

Fig. 1. Callopora weslawski Kuklinski and Taylor, 2006. (A) Arctic (Kara Sea, Holotype: Zoological Institute, ZN 20/3101), ovicellate zooid, unbleached. (B) Arctic (Holotype: ZN 20/3101) autozooids and ovicellate zooid at the the growing edge, bleached. (C) Antarctic $\left(71^{\circ} 18.35^{\prime} \mathrm{S}, 13^{\circ} 57.71^{\prime} \mathrm{W} ; 1030 \mathrm{~m}\right.$ depth; unfortunately this specimen was damaged during bleaching and only SEM images of unbleached material exist for this individual) ovicellate zooid on a sabellariid tube, unbleached. (D) Antarctic (7004.58' S, 03ำ19.66' W; $2190 \mathrm{~m}$ depth; Natural History Museum 2009.6.12.1) autozooids and ovicellate zooid at the the growing edge, bleached. Scale bars: $(\mathrm{A}, \mathrm{C}) 100 \mu \mathrm{m}$; (B,D) $200 \mu \mathrm{m}$

(colony development) can be ruled out. Several studies have shown that, even within species, zooid size can be influenced by seawater temperature, both in natural habitats and under laboratory conditions. There are also indications that zooid size varies with latitude (between colonies of the same species), which is probably driven by water temperature (Silén \& Harmelin 1976, Kuklinski \& Taylor $2008 b$ ) or possibly oxygen levels as a consequence of temperature (Hunter \& Hughes 1994, O'Dea \& Okamura 1999). The numbers of circumopesial mural spines and spines arising outside the mural rim seem to vary both within and between colonies of Callopora weslawski. These, therefore, are not stable taxonomical characters that could separate individuals from the Arctic and Antarctic into separate species. However, on average, a similar number of 
spines were found in individuals both from the Arctic (7) and Antarctic (8). The species occurs in both polar regions on similar firm substrates, typically rocks.

Ideally, morphological evidence of specimens comprising the same species would be supported by genetic investigation (at nuclear and mitochondrial loci). This requires immediate preservation in an appropriate solution, e.g. ethanol. However, this is problematic for cryptic lithophyllic taxa such as encrusting cheilostomes. They often occur on boulders too large for immersion in solution and their occurrence is not obvious without close inspection of the entire boulder surface. Additonally, they are not identifiable even to family or genus without stereomicroscopic examination. Thus most encrusting species collected using trawled apparatus are often only discovered after they are no longer viable for genetic analyses. Nevertheless, trawled bryozoan species may be preserved appropriately for genetics when they occur on smaller rocks and treatments are applied immediately to whole catches, such as when using EpiBenthic Sledges (see Kaiser et al. 2008). None of the Callopora weslawski specimens from deep Weddell Sea samples are viable for genetic testing, nor are any other deep Southern Ocean bryozoan species reported to date (e.g. see Gontar \& Zabala 2000).

\section{Possible mechanisms of bipolar occurrence}

Discontinuities in the distribution of marine taxa were recognized in the modern ocean at least $150 \mathrm{yr}$ ago (e.g. Darwin 1859). Fossil assemblage analyses suggest that bipolarity cannot be linked to just one major event in geological history, e.g. the Pangea break-up or PlioPleistocene glaciations (Crame 1993). There are suggestions that organisms from both hemispheres may have been able to breach the tropics repeatedly during the last 200 million yr (Lindberg 1991, Crame 1993, Stepanjants et al. 2006). Since the earliest fossil record of a member of Calloporidae, to which Callopora weslawski belongs, is from the Late Albian (ca. 100 million yr ago [mya]) (Taylor 1993, Ostrovsky et al. 2008), some geological events are unlikely as causal mechanisms underlying a bipolar distribution in this case. Establishment of a bipolar distribution of $C$. weslawski due to the Mesozoic fragmentation of Pangea (200 mya) is highly unlikely, not least because species rarely survive more than 10 million yr (Stanley 1975) and disjunct populations are unlikely to remain as one species without connectivity for such a considerable period. There were a number of more recent global cool phases in the geological past: e.g. Tithonian-Berriasian (ca. 145 mya) and Late Albian (ca. 100 mya). Crame (1993) suggested that cool phases may have led to the widespread distri- butions of certain ancestral taxa. Increased Southern Hemisphere sea surface temperatures through the Miocene from 6 to $12^{\circ} \mathrm{C}$ (see Zachos et al. 2001) increased latitudinal provinciality for a variety of planktonic taxa in both the Atlantic and Pacific Ocean basins (Lindberg 1991, Darling et al. 2000). These climatic and oceanographic changes may well have led to the establishment of a bipolar pattern of distribution of families and genera. Transequatorial transit and subsequent genetic exchange is likely to have increased during cooling periods associated with glacial cycling in the Quaternary period (the past 1.8 million yr). Low-latitude sedimentary records indicate the presence of subpolar planktonic foraminifera within the equatorial zone during these cooling cycles (McIntyre et al. 1989). Another possibility driving bipolar distributions is isothermal submergence, that is, passage through the tropics via off-shelf or abyssal currents (Stepanjants et al. 2006). The Weddell Sea (where C. weslawski specimens were sampled in the Antarctic) is a key source of Antarctic Bottom Water, which provides much of the deep water of the World Ocean. This water mass has been traced as far north as $56^{\circ} \mathrm{N}$ in the Atlantic Ocean (New \& Smythe-Wright 2001). Individuals of $C$. weslawski have been found in deep samples from both polar regions, which suggests that a deep transit might be a physiological and ecological possibility. The brief larval duration of species like C. weslawski would require many generations to travel so far. Although adults are sessile and larvae have a very short planktonic phase, their potential for travel may still be considerable because they encrust objects that may be carried in currents (such as polychaete worm tubes, which can break from attachment points). Futhermore, the life span of colonies may be considerable, allowing a single genetic individual to travel long distances.

Anthropogenic transport (e.g. widespread transport of fouling organisms in ship ballast waters) seems unlikely. In both areas, the species occur only in deep water (Arctic, down to $500 \mathrm{~m}$; Antarctic, 1000 to $2000 \mathrm{~m}$ ), thus recruitment onto ship hulls or occurrence in ballast water seems highly improbable.

Molecular techniques may prove the species from the Antarctic to be an undescribed cryptic species. However, there are now many examples in which disjunct morphospecies were found to be identical on a genetic level. For example, Darling et al. (2000) and Pawlowski et al. (2007) have found complete sequence identity between Arctic and Antarctic morphospecies of pelagic and benthic foraminifera, respectively. On the other hand, Pawlowski et al. (2008) were able to show genetic differentiation between morphologically identical Arctic and Antarctic monothalamous foraminifera. The widely distributed (but not bipolar) Celleporella hyalina complex is an example of a cheilostome 
bryozoan where morphologically similar species were separated into sibling species both using molecular and mating experiments (Gomez et al. 2007a,b). Morphological identity can be due to convergent or parallel evolution in similar environments, yet Briggs (1987) suggests that many species which currently persist with a discontinuous distribution and show little morphological divergence are likely to have had relatively recent interchange. In the case of Callopora weslawski, the level of morphological identity between individuals from the Arctic and Antarctic suggests that individuals are either of the same species or are at least sister species derived from a closely related ancestor. C. weslawski seems to be the strongest candidate to date of a bipolar benthic brooder.

Acknowledgements. The authors thank the scientists and crew of the R/V 'Polarstern' from the ANDEEP III and ANDEEP SYSTCO cruises, especially A. Brandt and K. Linse. We also thank S. Williams, A. Ostrovsky, R. Hughes and 3 anonymous reviewers for comments and corrections leading to an improved manuscript. The study was completed thanks to the financial support from the Polish Ministry of Science and Higher Education (539/N-CAML/2009/0).

\section{LITERATURE CITED}

Arntz WE, Gutt J, Klages M (1997) Antarctic marine biodiversity. In: Battaglia B, Valencia J, Walton DWH (eds) Antarctic communities: species, structure and survival. Cambridge University Press, Cambridge, p 3-14

Barnes DKA, Clarke A (1998) Seasonality of polypide recycling and sexual reproduction in some erect Antarctic bryozoans. Mar Biol 131:647-658

Boardman RS, Cheetham AH (1973) Degrees of colony dominance in stenolaemate and gymnolaemate Bryozoa. In: Boardman RS, Cheetham AH, Oliver WA Jr (eds) Animal colonies. Dowden, Hutchinson \& Ross, Stroudsburg, PA, p 121-220

Bock P (2009) Indexes to bryozoan taxa. Available at www. bryozoa.net/indexes.html

Briggs JC (1987) Antitropical distribution and evolution in the Indo-West Pacific Ocean. Syst Zool 36:237-247

Calvet L (1904) La distribution geographique des bryozoaires marins et la theorie de la bipolarite. C R Acad Sci 138: 384-387

Cook PL, Chimonides PJ (1985) Larval settlement and early astogeny of Parmularia (Cheilostomata). In: Nielsen C, Larwood GP (eds) Bryozoa: Ordovician to Recent. Olsen \& Olsen, Fredensborg, p 71-78

Crame JA (1993) Bipolar molluscs and their evolutionary implications. J Biogeogr 20:145-161

> Darling KF, Wade CM, Stewart IA, Kroon D, Dingle R, Leigh Brown AJ (2000) Molecular evidence for genetic mixing of Arctic and Antarctic subpolar populations of planktonic foraminifers. Nature 405:43-47

Darwin C (1859) The origin of species by means of natural selection, or the preservation of favoured races in the struggle for life. John Murray, London

Dunton KH (1992) Arctic biogeography: the paradox of the marine benthic fauna and flora. Trends Ecol Evol 7: 183-189
Ekman S (1953) Zoogoegraphy of the sea. Sidgwick \& Jackson, London

Gomez A, Hughes RN, Wright PJ, Carvalho GR, Lunt DH (2007a) Mitochondrial DNA phylogeography and mating compatibility reveal marked genetic structuring and speciation in the NE Atlantic bryozoan Celleporella haylina. Mol Ecol 16:2173-2188

Gomez A, Wright PJ, Lunt DH, Cancino JM, Carvalho GR, Hughes RN (2007b) Mating trials validate the use of DNA barcoding to reveal cryptic speciation of a marine bryozoan taxon. Proc R Soc Lond B Biol Sci 274:199-207

Gontar VI, Zabala M (2000) Bryozoa. In: Gutt J, Sirenko BI, Arntz WE, Smirnov IS, De Broyer C (eds) Biodiversity of the Weddell Sea: macrozoobenthic species (demersal fish included) sampled during the expedition ANT XIII/3 (EASIZ I) with RV 'Polarstern'. Ber Polarforsch 372:26-42

Gostilovskaya MG (1978) Bryozoa of the White Sea. Nauka, Leningrad (in Russian)

> Hageman SJ, Bayer MM, Todd CD (1999) Partitioning phenotypic variation: genotypic, environmental and residual components from bryozoan skeletal morphology. J Nat Hist 33:1713-1735

Hayward PJ (1995) Antarctic cheilostomatous Bryozoa. Oxford University Press, Oxford

Hayward PJ, Ryland JS (1990) Some Antarctic and subantarctic species of Microporellidae (Bryozoa: Cheilostomata). J Nat Hist 24:1263-1287

Hunter RL, Halanych KM (2008) Evaluating connectivity in the brooding brittle star Astrotoma agassizii across the Drake Passage in the Southern Ocean. J Hered 99:137-148

Hunter E, Hughes R (1994) The influence of temperature, food ration and genotype on zooid size in Celleporella hyalina (L.). In: Hayward PJ, Ryland JS, Taylor PD (eds) Biology and palaeobiology of bryozoans. Olsen and Olsen, Fredensborg, p 83-86

Jazdzewski K, Weslawski JM, de Broyer C (1995) A comparison of the amphipod fauna diversity in two polar fjords: Admirality Bay, King George Island (Antarctic) and Hornsund, Spitsbergen (Arctic). Pol Arch Hydrobiol 42:367-384

Kaiser S, Barnes DKA, Linse K, Brandt A (2008) Epibenthic macrofauna associated with the shelf and slope of a young and isolated Southern Ocean island. Antarct Sci 20:281-290

Kluge GA (1975) Bryozoa of the northern seas of the USSR. Smithsonian Institution, Washington, DC

- Kuklinski P, Bader B (2007) Diversity, structure and interactions of encrusting lithophillic macrofaunal assemblages from Belgica Bank, East Greenland. Polar Biol 30: 709-717

> Kuklinski P, Taylor PD (2006) A new genus and some cryptic species of Arctic and boreal calloporid cheilostome bryozoans. J Mar Biol Assoc UK 86:1035-1046

Kuklinski P, Taylor PD (2008a) Arctic species of the cheilostome bryozoan Microporella, with a redescription of the type species. J Nat Hist 42:1893-1906

Kuklinski P, Taylor PD (2008b) Are bryozoans adapted for living in the Arctic? In: Hageman SJ, Key MMJ, Winston JE (eds) Bryozoan Research 2007. Proc 14th Int Bryozool Assoc Conf. Special Publication no. 15, Virginia Museum of Natural History, Martinsville, VA, p 101-110

Levinsen GMR (1916) Bryozoa. Danmark-Ekspeditionen til Grönlands Nordöstkyst 1906-1908. Medd Gronl 16: 433-472

Lindberg DR (1991) Marine biotic interchange between the northern and southern hemispheres. Paleobiology 17: 308-324

McIntyre A, Ruddiman WF, Karlin K, Mix AC (1989) Surface water response of the equatorial Atlantic Ocean to orbital forcing. Paleoceanography 4:19-55 
Moyano HI (1982) Magellacic Bryozoa: some ecological and zoogeographical aspects. Mar Biol 67:81-96

New AL, Smythe-Wright D (2001) Aspects of the circulation in the Rockall Trough. Cont Shelf Res 21:777-810

O'Dea A, Okamura B (1999) Influence of seasonal variation in temperature, salinity and food availability on module size and colony growth of the estuarine bryozoan Conopeum seurati. Mar Biol 135:581-588

Ostrovsky AN, Taylor PD (1996) Systematics of some Antarctic Idmidronea and Exidmonea (Bryozoa: Cyclostomata). J Nat Hist 30:1549-1575

Ostrovsky AN, Taylor PD, Dick MH, Mawatari SF (2008) PreCenomanian cheilostome Bryozoa: current state of knowledge. In: Okada $\mathrm{H}$, Mawatari SF, Suzuki N, Gautam P (eds) Origin and evolution of natural diversity. Proc Int Symp, 1-5 Oct 2008, Sapporo, p 69-74

Pawlowski J, Fahrni J, Lecroq B, Longet D and others (2007) Bipolar gene flow in deep-sea benthic foraminifera. Mol Ecol 16:4089-4096

Pawlowski J, Majewski W, Longet D, Guiard J and others (2008) Genetic differentiation between Arctic and Antarctic monothalamous foraminiferans. Polar Biol 31:1205-1216

Editorial responsibility: Roger Hughes,

Bangor, UK
Ross JCA (1847) Voyage of discovery and research in the Southern and Antarctic Regions, during the years 1839-43. John Murray, London

Ryland JS (1974) Behaviour, settlement and metamorphosis of bryozoan larvae: a review. Thalassia Jugosl 10:239-262

Schopf TJM (1976) Environmental versus genetic causes of morphologic variablility in bryozoan colonies from the deep sea. Paleobiology 2:156-165

Silén L, Harmelin JG (1976) Haplopoma sciaphilum sp. n., a cave-living bryozoan from Skagerrak and the Mediterranean. Zool Scr 5:61-66

Stanley SM (1975) A theory of evolution above the species level. Proc Natl Acad Sci USA 72:646-650

Stepanjants SD, Cortese G, Kruglikova SB, Bjorklund KR (2006) A review of bipolarity concepts: history and examples from Radiolaria and Medusozoa (Cnidaria). Mar Biol Res 2:200-241

Taylor PD (1993) Bryozoa. In: Benton MJ (ed) The fossil record. Champan \& Hall, London, p 465-487

Zachos J, Pagani M, Sloan L, Thomas E, Billups K (2001) Trends, rhythms, and aberrations in global climate $65 \mathrm{Ma}$ to present. Science 292:686-693

Submitted: September 28, 2009; Accepted: December 1, 2009 Proofs received from author(s): February 11, 2010 